\title{
The Contribution of CSR in Empowering The Community Through The Utilization of Cow Manure in The Areng Village, Cibodas
}

\author{
Jubaidah Hasibuan and Friska Indria Nora Harahap \\ Department of Non Formal Education, Indonesia University of Education \\ Bandung, West Java, Indonesia \\ Email Address: jubaidahhsb@student.upi.edu
}

\begin{abstract}
Corporate Social Responsibility is an activity realizing social action and environmental improvement, for sustainable economic development to improve Self-Reliant Communities, quality of life and friendly environment that is useful for both the company and the local community. The purpose of this study is to analyze the pattern of implementation of CSR program in Kampungareng, Research focuses on CSR programs related to community empowerment to realize the selfreliant communities. CSR were practiced in Kampung Areng through biogas program, one of the co-operation program KPSBU (Cattle Breeders Cooperative North Bandung) and PT Energi Persada Bandung. In this study, using qualitative approach and Sampling method is done by using the technique of purposive sampling. The data is taken from document review and in-depth interview to local the community and village government. The findings showed that the implementation of CSR could increase the awareness and willingness to communities with waste utilization of cow manure as a primary source of biogas. The results of the program are people who are able to process the waste become renewable energy and fertilizer. In addition, people can reduce the dependence on LPG (Liquefied Petroleum Gas) for their daily needs and reduce pollution caused by waste, the creation of a dynamic society and harmony with the environment and finally, these ways is an important aspect that should be the main focus for CSR programs, which has the principle of empowerment, such that the result is a self-reliant communities on various aspects.
\end{abstract}

Keywords: Corporate Social Responsibility, Community Empowerment, Self-Reliant Communities

\section{INTRODUCTION}

Corporate Social Responsibility (CSR) is a commitment in the business world to be able to provide contribute to the development. The emergence of CSR is influenced by the phenomenon of DEAF (Dehumanization, the emancipation, Aquariumisasi, and Feminization). This phenomenon raises the commitment related to sustainable development. Companies must demonstrate that resources are being used effectively and that community initiatives positively contribute to sustainable development (Sharma and Bhatnagar). The industry does not only have a focus on the business benefits increase, but also have a special role to participate in the social responsibility to the community. These responsibilities become one of the effort to overcome the increasingly complex problems in society.

The problems that currently present in the community can be solved with the joint efforts of all parties as Widayanti delivered [1] resolve social problem, especially poverty, can be conducted by various elements start from the government, business world and community. CSR activities can be linked with national priorities such as poverty alleviation, education, skill development, family planning, community development, health awareness, etc. (Basargekar) [2]. The presence of CSR is one of mobilize development of this nation. The discussion on CSR started to gain momentum in academic and research circles in early 1950s. There were an increasing number of economists and social scientists who argued that firms should work in conjunction with community interest and thereby make greater contributions towards socio-economic development and welfare of people [3] [4].

The form of CSR which is often done in Indonesia is one of the forms of community development stresses rather than the development of social and community capacity, which will explore the potential for local communities to become progressing and developing social capital. The stagnation results from a process whereby the power associated with CSR increases, causing the potential power of individuals with CSR responsibilities inside organizations to also increase [5]. This will build your company image friendly and care with the environment and the community trusts it.

The practice of CSR is currently considered can cause dependence, this is because not all the companies implement CSR obligations which should give strength to the community but otherwise is making the community becomes the dependence which resulted in the public becoming weaker. Although conducted, CSR occurs is a public relation only so impressed imagesentris. The form of CSR is like this only emphasized on aid to the community only. A primary motivation for organizations engaging in CSR activities is to attract customers, shareholders, or donors [6] but not all CSR like that. Such as in the Areng Hamlet Cibodas village that has been implementing the CSR function from the Hivos institute. So this study aims to determine how the contribution of CSR in empowering the community through the use of cow manure. 


\section{FRAMEWORK \& EMPIRICAL STUDIES}

Corporate Social Responsibility (CSR) as the commitment that must be carry out by the business world as one of the steps in supporting of development. The commitment is explicitly has clearly become the responsibility that is required to be implemented. At the national level is regulated by law, namely Law Number 25 Year 2007 on Capital Investment, in law No. 40/2007 about Limited Company, and the Regulation of the Minister of State Owned Enterprises Number Per5/MBU/2007 about BUMN partnership program with small businesses and Environmental Development Programs, special for companies BUMN. After that corporate social responsibility is listed again in law No. 40/2007 about Limited Company Article 74 (1) the company to do activities in the field and or related to natural resources required to carry out the social and environmental responsibility. (2) The obligation is calculated as the cost of the company that its implementation is done with attention to meritocracy and fairness. (3) Refers to the company that does not perform the obligation referred to verse (1) subject to sanctioned in accordance with the legislation relevant. And (4) stating further provisions regarding social and environmental responsibility is regulated by the Government. When examined, the regulations on CSR more detailed is the Law No.19 of 2003 on BUMN which elaborated by the Regulation of the Minister of State Enterprises No.4/2007 which set the starting amount of the funds to the procedures of CSR.

Implementation of CSR programs is usually voluntary and driven by various international assessments, such as the ISO 9001 quality management system and ISO 14001 as the environmental management system. Currently the parties are waiting ISO 26000 as a guide to social responsibility. That later became the standard of hope as a reference for all States and all parties who developed the concept of CSR. It indicated the progress of ISO 26000 is not only the company are charged with the responsibility towards the social and environmental aspects, but all stakeholders, such as communities, academics, NGOs, and government.

The views Corporate Social Responsibility (CSR) According to Smith is defined as a business system that enables the production and distribution of wealth for the betterment of stakeholders through implementation and the integration system and sustainable management practices. Accordingly, According Widjaja\& Jeremiah CSR is a form of cooperation between companies (not just a limited company) with everything (stakeholders) that directly or indirectly interact with the company to still ensure the existence and survival of the business (sustainability) of the company [7].

Company and CSR are one thing that cannot be separated. The company with its main goal is to get the advantage of the production must have relevance to the community and environment. The concept of corporate social responsibility (CSR) has grown with the recognition that business enterprises have responsibilities to society well beyond profit making [8]. Therefore, CSR activities should have become an indispensable part of a company. CSR programs have positive effects for the development of society. With the CSR, the public will be able to solve their problems. Such as less creative and productive, quickly satisfied with what is obtained, resigned to fate, consumptive and wasteful attitudes [9].

Researcher previously conducted by the Zone which criticized the CSR programs of Bank Nagari Branch Pangkalan does not provide long-term benefits for social and economic of local communities. Bank Nagari in general and banks in particular Nagari Branch Pangkalan, So recommended to carry out CSR programs based on community empowerment so that the impact of the program can be perceived by the public in the long term.

Other studies related to CSR as written by Leimona\&Fauzi is as follows:

CSR conducted by PT Titrta Invesatama (Danone Aqua) in Klaten, Central Java, in collaboration with NGOs to rehabilitate degraded land and planting 50.000 trees that also involves local farmers group and the Ministry of Forestry and Environment. Processing of waste plastics / bottles in Bali making conservation parks in Mekarsari.

CSR conducted by Unilever Peduli focused on four areas, namely: Development of small and medium businesses, preservation of water resources, Recycling, and public health education. In the field of preservation of water resources Unilever was made clean river project in Jambangan, Surabaya, which change the perspective and behavior of the society along the Brantas River in addressing the river. In 2005 Unilever also organizes Surabaya Green and Clean, an environmentally clean campaign program of cooperation with city officials and local NGOs.

PT Coca Cola with CSR concept is the use of water with WUR (Water Usage Ratio) and Smart Waste. Environmental education programs in schools, the program "Cinta Air" which consists of the activities of times cleaner, waste sorting

and improved sanitation

PDAM Cirebon do CSR with levy payments to the government of Kuningan Regency as an effort to preserve water sources and community activities around the forests.

PT Semen Gresik Tbk with its CSR was the production of the green line in the former mining area, help clean river activities, the making of the source absorbed and reservoirs for use as operations [10].

CSR conducted by Kitadin of juggling holes mine exploration into fish ponds managed by all of society.

\section{METHODOLOGY RESEARCH}

In this research using qualitative approach to describe the implementation of CSR in the field of processing manure into biogas in Areng Hamlet Cibodas village lembang district. Moleong said qualitative research is intended to understand the phenomena of what is experienced by the subject of research for example behavior, perceptions, motivation, actions, and others, by a holistic and with the way the description in the form of words and language on a specific context that natural processes and by using various natural methods [11]. And this study using case study design, as the case study is found in many research fields, such as, evaluating, 
developing in-depth analysis of a case, program, event activities, processes, or one or more individuals. And the case of restricted ole time and activities, and research collect complete information using a variety of data collection procedures based on a predetermined time [12]. Sampling method is done by using the technique of purposive sampling means determined according to the requirements of a sample that reflects the population, can be seen from the feasibility and the authority of the respondents to provide information.

The technique of data collection in this research using the interview, observation and study the literature. Interview done to community leaders because it is considered to have original capacity information the required about the history and the response of the public to CSR in the Cibodas village. The observation done aims to see directly the condition of the society that has been getting the impact of empowerment conducted by CSR program. And the study of literature in this research review and Analyzing sustainability report CV Energy Persada and studies of literature that have relevance. In this research is more focused on the phenomenon of CSR contribution in empowering society through the use of cow manure.

\section{DISCUSSIONS ON EMPIRICAL RESULTS}

Areng Hamlet Cibodas Village is a region with the characteristics of the population who work as farmers, breeders and farm worker. Initially community in Areng hamlet using manure only as organic fertilizer for their crops and the others distributed to farmers who did not have their own cattle. Apart from the benefits of manure, which can be used as organic fertilizer actually there is a big problem that caused by manure, which is too many and have polluted the river was around the area. So many people who fretted as a result of water pollution. Manure will be swept away by the water into the ground and the river which then pollute the ground water and river water. Manure contains poison and bacteria Colly which endanger human health and the environment.

Cattle ranchers Areng hamlet distribute results dairy milk to the co-operative Milk Breeder north Bandung (KPSBU). The distribution of dairy milk done by cattle ranchers as much as two times the morning and evening. Through the distribution occurs communication between cattle ranchers and KPSBU side. In carrying out its function as a cooperative, KPSBU not only as a business center for investment and as a cow milk marketing but also become partners of the community in addressing the problems faced by the society for the welfare of the community. Then as a partner, KPSBU a mediator between cattle ranchers with CV. Energy Persada in making the biogas reactors that could be useful to overcome manure.

Cooperatives are not only instrumental in providing loan capital but also help solve community problems in realizing the independent community that is by empowering the community through the use of cow manure. Empowerment in real is the enhanced ability of any person to make best possible choice from better alternatives available to spend life affairs. This enhanced ability puts back the initially confined ability to make such choices [13]. Therefore, Empowerment is basically an increase in the ability of a person to make important decisions regarding different alternatives of life [14].

CSR comes with provide innovation to the public through the manure, processing into biogas. For the people of the village Areng, biogas program is innovation in solving the problems in the environment community. Innovation represents the "implementation of a new or significantly improved product (good or service), or process, a new marketing method, or a new organizational method in business practices, workplace organization or external relations [15]. Innovation is not present by itself in the middle of the community. But with the dissemination of information in advance. Whether it is directly or indirectly. In this case, the spread of the information society is done with two stage communication. Two communication this stage comes from Lazarsfeld, Berelson, and Gudet based on research states that the ideas often come from the radio and newspapers that were arrested by the nobles and the opinion of them is passed according to the inhabitants of that less intense[16]. The first phase of the CSR as effective communicators deliver information to community leaders. Then on the second stage of community leaders to convey to all members of the community which also includes the spread of influence.

To select the method to communicate effectively, Mardikanto introduced the three approaches that can also be applied in the selection of community empowerment method that is based on the media used, the nature of the relationship between the facilitators and beneficiaries, and psychosocial approaches are associated with the stages of adoption [17]. With regard to the opinion, in the dissemination of information to the public is done with the use of the oral media delivered directly and also by using the media projected image in the form of a picture or slide.

Description of the contribution of CSR in empowering the community in Areng village can be seen in the picture below:

This template, modified in MS Word 2007 and saved as a "Word 97-2003 Document" for the PC, provides authors with most of the formatting specifications needed for preparing electronic versions of their papers. All standard paper components have been specified for three reasons: (1) ease of use when formatting individual papers, (2) automatic compliance to electronic requirements that facilitate the concurrent or later production of electronic products, and (3) conformity of style throughout a conference proceedings. Margins, column widths, line spacing, and type styles are builtin; examples of the type styles are provided throughout this document and are identified in italic type, within parentheses, following the example. Some components, such as multileveled equations, graphics, and tables are not prescribed, although the various table text styles are provided. The formatter will need to create these components, incorporating the applicable criteria that follow. 


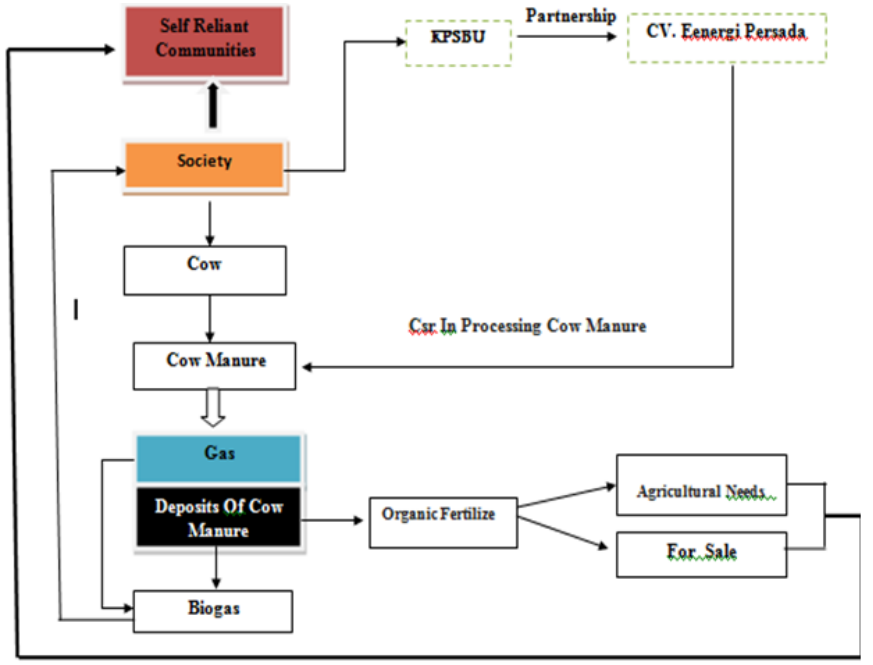

Fig. 1. Overview of empowerment through the use of cow manure

The spread of innovations to the community does not directly received by the community. But through some process that planned, detailing the stages of community empowerment activities into seven main activities are as follows:

\section{A. Awareness}

On the stage of awareness, CSR gives instruction about the potential in the community that many people who have cattle.

\section{B. Indicates a problem}

In this case, CSR gives instruction about the impact caused by the multitude of manure, which will pollute the environment in the community.

\section{Help}

CSR troubleshooting help solve the problem by giving them the opportunity to take advantage of the cow manure into biogas.

\section{Shows the importance of the changes}

Through dissemination, CSR shows the importance of the changes because of the condition of the environment continues to experience the changes that the faster then the community must also be prepared to anticipate these changes.

\section{E. Testing and demonstration}

Testing and demonstrations done through the practice of making the biogas directly involving community leaders.

\section{F. Produce and the publication of the information}

After the demonstration (test) by community leaders, then biogas innovation in publish to all the people of the village Areng.

\section{G. Implement empowerment/strengthening the capacity}

After the produce and the publication of information, CSR provides an opportunity to the community to manage the program of biogas through farmer groups without removing the control social standing.

With the innovations made by CSR through community empowerment, there has been a change of behavior in society. Aspects of behavioral changes that occur in society areng village after their biogas program refers to the concept of Bloom's Taxonomy. The model is regarded as a concise model for the analysis of educational outcomes in the cognitive area of remembering, thinking, and problem solving [18]. This taxonomy classifies the goals or objectives of education into three domains (domains department): cognitive, affective, and psychomotor and each of those realms subdivided into more detailed division by hierarchy, as follows:

\section{H. The cognitive aspect}

On cognitive aspects, the people have no prior knowledge about the use of cow manure. After that understands processing cow manure into biogas. Then people are able to apply biogas production process that has been demonstrated by CSR. In the application of the public is able to analyze and synthesize the impact of the empowerment program. Finally stage of this aspect is that people are able to evaluate the activities that have been done.

\section{Affective aspect}

In the aspect of affective, behavioral change is indicated by the acceptance of innovation. Then people participated on the program utilization cow manure into biogas conducted by CSR. Furthermore, the public has a decision to accept the program and accept the consequences of participation in the program.

\section{J. Aspects of psychomotor}

Psychomotor aspect is the change in society have seen improved skills. The public has been aware of the problems caused by the accumulated manure. Furthermore, the community participated in the utilization of cow manure into biogas. Then implement the biogas production process by imitating that has been demonstrated through the instructions given. After that, the public is able to autonomously in biogas production.

Through a two-stage communication, innovation has spread evenly to the entire community areng village. The role of community leaders is the key to success in community development programs through the use of cow manure into biogas.

Follow-up of CSR contribution in empowering the community through the use of cow manure are now widely installed biogas reactor fix dome models for cooking needs. Some also have the light of biogas for lighting around the stalls for cows. As for the installation of housing biogas reactor just have two cows only. Exodus from the biogas reactor in the form of pulp biogas (bio slurry) used for fertilizer, reducing the cost of agricultural production. Previously most of the needs of a mixture of manure fulfilled from the outside, for example chicken droppings are combined with fresh manure. Now most of the needs of mixed material they can fill from the results of 
the exodus of the reactor biogas. With the existence of the biogas reactor then composting manure more efficient.

Families who use the biogas is not require the purchase of fuel because it is already fulfilled from manure whichgroweth. Manure is now become very valuable, therefore the farmers will be diligent care for his cattle so that the condition of the stalls are clean and the health of the cattle for the better. The family farmers who typically use chemical fertilizers to plant, now can minimize the cost of agricultural production because it is already available organic fertilizer in sufficient numbers and quality of fertilizer which is better.

\section{CONCLUSION}

Formation or cooperatives is a crucial and strategic to strengthen institutions of the local economy and improving the welfare. Similarly, the Dairy Farmers Cooperative North Bandung (KPSBU) which has provided convenience to the public in terms of capital in the form of loans and fee waivers that is dairy milk so that the people can have the appliance Biogas processing. In addition to providing a cooperative venture capital CSR bridge with the community especially cattle ranchers who have difficulty in tackling the manure. The implementation of CSR should be based on problem solving by the community. In fact CSR not only the form of temporary relief but also help to achieve sustainable self-reliant community.

CSR will not be there are endless as long as the company it is still standing and the community still has many issues that must be addressed. If the company does not perform CSR, it means that is not doing business and CSR is at the heart of the business activities. And not all types of issues can be resolved by one type of CSR. The company as a CSR for the community is expected to remain a community partners in tackling the problem even though the function of the CSR is no longer directly provide assistance, but can only as a means to meet people with other CSR is considered in line or in accordance with the issues that are being faced by the community. For a partnership that continuously between the company and the community is not removed from the community participation an each of the existing CSR program.

With the CSR provided by PT Energi Persada was gave a very positive impact and help many people not only in the prevention of manure fitful, but also assist communities in providing gas so that it can be categorized in the independent community.

\section{ACKNOWLEDGMENT}

The author thanks to the Department of Non Formal Education, Postgraduate School of education in Indonesia, which has provided an opportunity for writers to contribute in this research.

\section{REFERENCES}

[1] Widayanti, S. (2012). Pemberdayaan Masyarakat: Pendekatan Teoritis. Jurnal Ilmu Kesejahteraan Sosial, Vol.1, No.1.
[2] Basargekar, P. (2009). Economic Empowerment Through Microfinance An Assessment of CSR Activity run by Forbes Marshall Ltd. International Journal Business Insights \& Transformation,

[3] Freeman, R E 1984, Strategic management. A stakeholder approach, Pitman Marshfield, MA.

[4] Schuman, M C 1995, 'Managing legitimacy: strategic and institutional approaches', Academy of Management Review, vol. 20, no. 3, pp.571610 .

[5] Bondy, K. (2008). The Paradox of Power in CSR: A Case Study on Implementation. Journal of Business Ethics 82, 307-323.

[6] Carroll, A.B., \& Shabana, K.M. (2010). The business case for corporate social responsibility: A review of concepts, research and practice. International Journal of Management Reviews, 12(1), 85_105.

[7] Widjaja, G., \& Yeremia, A. P. (2008).Risiko Hukum dan Bisnis Perusahaan Tanpa CSR. Jakarta: Forum Sahabat.

[8] Suharto, Edi. (2009). Pekerjaan Sosial di Dunia Industri. Bandung: CV. Alfabeta.

[9] Pandaleke. A.(2015). Empowerment Of Coastal Communities Through The Optimization Of Social Capital In Improving The Well-Being Of Families In The Village Tumbak Southeast Minahasa District Of Pusomaen North Sulawesi Indonesia. Research on Journal of Humanities and Social Sciences. Vol.5, No.14.

[10] Leimona, B. \& Fauzi, A. (2008). CSR dan Pelestarian Lingkungan, mengelola Dampak positif dan Negatif. Jakarta : Indonesia Business Links.

[11] Moleong, L.J.(2006). Metodologi penelitian kualitatif. Bandung: Remaja Rosdakarya.

[12] cresswell, J.W. (2014). Research Design, Qualitative, Quantitative and mixed methods approaches, Fourth edition, Sage Publication, Inc., Copyright

[13] Kabeer, N. (2001). Conflicts over credit: re-evaluating the empowerment potential of loans to women in rural Bangladeshl. World Development, vol 29, no. 1.

[14] Nawaz, N. (2012). Empowering Women Through Microcredit: A Case Study Of Tameer Microfinance Bank, Bahawalpur. Journal of Economics and Sustainable Development. Vol.3, No.6.

[15] Kadar, M. (2014). Innovation Management in The Globalization Digital Society. Procedia-Social and Behavioral Sciences 143 (2014) 1083 1089.

[16] Lazarsfeld, Paul F, Bernard R. Berelson, and Hazel Gaudet. (1948). The People's Choice: How the Voter Makes Up His Mind In a Presidential Campaign. 2nd edition. New York: Columbia University Press.

[17] Mardikanto, T \& Soebiato, P. (2015). Pemberdayaan Masyarakat Dalam Perspektif Kebijakan Publik. Bandung: Alfabeta.

[18] Ahmed, N. (2014). Bloom's Taxonomy Based Proportionate Curriculum Development Model. Journal of Education and Practice, IISTE.Vol.5, No. 26 